\title{
Shotcrete ribs and cemented rock fill ground control methods for stoping in weak squeezing rock at Wattle Dam Gold Mine
}

\author{
P. Marlow Ramelius Resources Pty Ltd, Australia
}

P.A. Mikula Mikula Geotechnics Pty Ltd, Australia

\begin{abstract}
Wattle Dam Gold Mine has successfully mined a significant gold orebody in very weak rock, where some of the ore strength was less than $1 \mathrm{MPa}$. Almost 100\% ore recovery was achieved despite the weak rock.

Conventional rockbolts did not achieve high anchorage capacities in this material. As mining extended to depth, squeezing developed in the rock mass. The mine trialled several ground control options in response to developing hazards and implemented two of them successfully. The first was shotcrete ribs for long-term control. The ribs were installed after allowing some squeezing movement to occur. Novel methods were developed to easily fabricate mesh for the ribs. The second option was cemented rock fill (CRF) for backfill of stope panels in order to control convergence and overbreak. Novel crush firings were used to allow blasting of stopes without conventional rises being required.
\end{abstract}

\section{$1 \quad$ Introduction}

Wattle Dam Gold Mine, operated by Ramelius Resources Ltd, has successfully mined a significant gold orebody in very weak rock, achieving near $100 \%$ ore recovery within budget targets.

The Wattle Dam underground operations near Widgemooltha, Western Australia, commenced in 2009 followed the completion of an open pit stage. The nominal production rate was 15,000 t ore monthly until the deposit was fully mined out in October 2012. In the final months, the production rate exceeded $30 \%$ above target due to the excellent performance of the stopes and the ground support strategies. Operations were carried out by HWE Mining (now Leighton Mining) under contract.

Geotechnically, the most significant feature of the deposit was the very weak strength of the ore, often less than $1 \mathrm{MPa}$. Conventional friction bolts did not achieve high anchorage capacities in the weak rock material. Then as mining extended to depth, up to $360 \mathrm{~m}$ below surface, squeezing developed in the rock mass.

The mine trialled various ground control options in response to developing hazards, modified them to suit, and implemented them successfully. Targets were met for effective production - there were very few unplanned falls of ground, and rehabilitation strategies were successful.

This paper focuses on the characteristics of the squeezing ground, and the shotcrete ribs (Figure 1) and CRF practices that were used to adequately manage that ground. The mine experienced a wide range of other conditions common to many mines, but these are outside the scope of this paper.

\section{Geomechanics: geology, lithology, stress}

\subsection{Geology and structure of the deposit}

Local stratigraphy of the Wattle Dam deposit consisted of a sequence of steep west-dipping metamorphosed ultramafic, sedimentary and basaltic units. The gold lode mineralisation zone was a major 
structural feature, being an altered shear zone within the ultramafic. The lode was generally 8 to $15 \mathrm{~m}$ wide with an economic strike length of 30 to $60 \mathrm{~m}$, and a depth extent of about $300 \mathrm{~m}$.

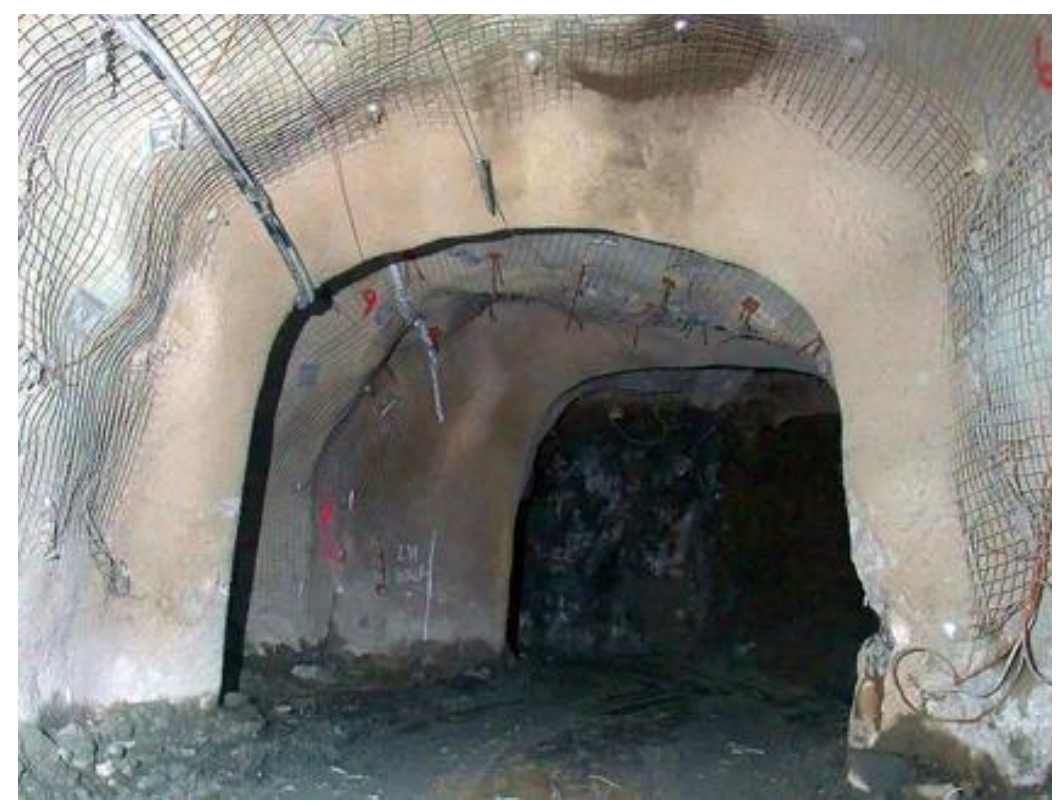

Figure 1 A pair of shotcrete ribs installed for control of wide span backs at Wattle Dam

The hangingwall west side of the lode was a tremolite-chlorite ultramafic. Further to the west were a schistose unit, and then a good quality basaltic sediment rock. The footwall side comprised a finer grained actinolite-chlorite ultramafic unit. The mine access and infrastructure were located in the better quality hangingwall rock mass.

The major faults were the west-dipping Charger fault which formed the top cutoff to the lode, and the subvertical Regal fault which was well clear to the west of the lode. Another structure, the Graphite Shear, was located in the sediment also well clear of the lode. It had significant water inflow.

On smaller scales, various joints and structures were present. These generally had relatively little continuity. Defect surface profiles tended to be gently undulating, smooth, with chlorite, carbonate or clay infill. Foliation was parallel to strike and was variably developed across the site.

Rock weathering depths were typically 50 to $60 \mathrm{~m}$, but some areas of deeper oxidation near the Regal fault were encountered down to $155 \mathrm{~m}$ depth.

\subsection{Groundwater}

The water table was at $46 \mathrm{~m}$ below surface. Groundwater inflows to underground workings were initially high but then reduced. There were inflows from the Graphite Shear at various depths, and often from exploration boreholes intersected by underground development.

Water is a destabiliser in weak ground as it reduces the effective stress and thus the shear strength of rock. This was a contributing factor to the squeezing ground. Weak ground preferably should be drained.

\subsection{Rock strength}

Some exploration holes encountered very weak or rubble zones within the ultramafic, i.e. gravel, sand and silty fragments, with no or very few pieces of broken core. In one case (Figure 2) a large amount of fragments was recovered from just a short core interval. This indicated that the material was washed out, or caved into the borehole, leaving a large cavity behind.

Selected strength test data for the immediate hangingwall and footwall of the lode are shown in Table 1. The lode ore itself was too weak to be suitably sampled for laboratory testing. For the ore, the typical 
material could be easily penetrated by thumb nail, and crushed in the hand, indicating an in situ strength estimate of less than about $1 \mathrm{MPa}$, perhaps only $0.5 \mathrm{MPa}$.

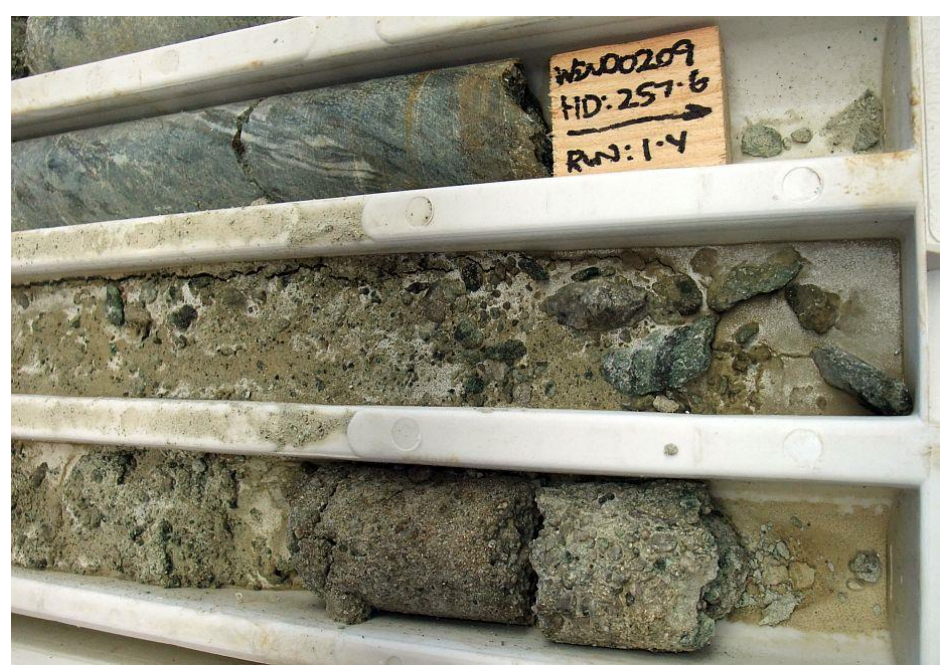

Figure 2 Fragments recovered from borehole WDUD209

Table 1 Selected laboratory test data for material adjacent the ore

\begin{tabular}{lccccc}
\hline \multicolumn{1}{c}{ Rock Type } & $\begin{array}{c}\text { Approx. } \\
\text { Depth }(\mathbf{m})\end{array}$ & $\begin{array}{c}\text { Density } \\
\left(\mathbf{t} / \mathbf{m}^{3}\right)\end{array}$ & $\begin{array}{c}\text { UCS } \\
(\mathrm{MPa})\end{array}$ & $\begin{array}{c}\text { Elastic } \\
\text { Modulus (GPa) }\end{array}$ & $\begin{array}{c}\text { No. of } \\
\text { Tests }\end{array}$ \\
\hline $\begin{array}{l}\text { Hangingwall ultramafic, with moderate } \\
\text { chlorite alteration }\end{array}$ & 230 & 2.84 & 25 & 8.8 & 1 \\
$\begin{array}{l}\text { Hangingwall ultramafic } \\
\text { Hangingwall ultramafic }\end{array}$ & 241 & 2.81 & 23 & 11.4 & 1 \\
$\begin{array}{l}\text { Hangingwall ultramafic, remnant within } \\
\text { lode zone }\end{array}$ & 289 & 2.68 & 8 & 1.6 & 1 \\
$\begin{array}{l}\text { Footwall ultramafic, weak/moderate } \\
\text { chlorite alteration }\end{array}$ & 336 & 2.89 & 39 & 28.8 & 1 \\
\hline
\end{tabular}

One result of the weak strength of the ore was that boreholes in ore were badly affected by washout during drilling, causing diameter increase. The result for example was that the jumbo was able to drive a $47 \mathrm{~mm}$ jumbo Split set into a $35 \mathrm{~mm}$ diameter hole. It was not unexpected that friction bolts in ore had low capacity (in situ proof load tests of installed bolts indicated $15 \mathrm{kN} / \mathrm{m}$ anchorage).

\section{$2.4 \quad$ In situ stress regime}

Based on the geological structural setting, the likely stress field was assumed to be as per Table 2 . No stress measurement was undertaken. Stresses were too low to be successfully measured using conventional methods such as the Hollow Inclusion overcore.

The stress field was also estimated from observations of squeezing. For example significant squeezing in ore first occurred on 40 Level, $300 \mathrm{~m}$ below surface. In that case the failure strain in the walls was estimated at $0.12 \%$ (based on observation of the buckling geometry of thin slabs in the walls). For a modulus of $10 \mathrm{GPa}$, this implied a stress of $12 \mathrm{MPa}$ in the walls. 


\subsection{Q system characterisation and ground support requirements}

Table 3 presents the Barton Q-system summary of the rock domains and characterisation (Barton et al., 1974). All rock types included localised and apparently random poor zones (structured, slickensided, slabby, weaker strength) within a better quality rock.

Table 2 Assumed stress field in Wattle Dam at $200 \mathrm{~m}$ depths (pro-rata for other depths)

\begin{tabular}{clc}
\hline Component & \multicolumn{1}{c}{ Assumed Orientation } & Assumed Magnitude \\
\hline Sigma-1 & $\begin{array}{l}\text { In the plane of the foliation and along strike of the major } \\
\text { faults, i.e. subhorizontal trending NNW-SSE }\end{array}$ & $10 \mathrm{MPa}$ \\
Sigma-2 & Normal to the major fault planes, i.e. shallow dip to the ENE & $6.7 \mathrm{MPa}$ \\
Sigma-3 & Subvertical & $5 \mathrm{MPa}$ \\
\hline
\end{tabular}

In all rock types, unravelling tended to dominate over wedge formation, and wedge analysis was rarely required. Therefore support demand estimation was based on the $\mathrm{Q}$ data supplemented by visual observations of performance during excavation. The variability of the rock mass was reflected by choosing the $25^{\text {th }}$ percentile $Q$ values in estimating the ground support demand.

These support demands indicated that typical rock and ore would require 50 to $90 \mathrm{~mm}$ shotcrete, and bolt spacing of 1.4 to $1.7 \mathrm{~m}$. The poor quality zones required additional shotcrete. Weak ore required $200 \mathrm{~mm}$ of shotcrete, which was approximated by the installation of shotcrete ribs as described below.

The adopted Ground Support Schemes (GSS) for ore drives are shown in Table 4. Two schemes were in use, being either with or without shotcrete ribs.

Spiling bolts (splitsets) generally controlled ore backs in development. Spiling bolts were effective to support subvertical joint planes, to assist with control of weak or unravelling ground, or any situation where backs failure is expected. Spiling bolts were placed as a fan of bolts less than $0.8 \mathrm{~m}$ apart, angled about $10^{\circ}$ above horizontal, prior to taking a cut.

Table 3 Indicative support requirements for conservative $Q$ data. These requirements are estimated for a depth of $200 \mathrm{~m}$ below surface

\begin{tabular}{lccccc}
\hline Rock Type & $\begin{array}{c}\text { Typical } \\
\text { Strength } \\
\text { (MPa) }\end{array}$ & $\begin{array}{c}\text { Q 25th } \\
\text { Percentile }\end{array}$ & $\begin{array}{c}\text { Maximum Stable } \\
\text { Unsupported Span } \\
\text { for Permanent } \\
\text { Opening }(\mathbf{m})\end{array}$ & $\begin{array}{c}\text { Suggested } \\
\text { Support } \\
\text { Pressure in } \\
\text { Drives }\left(\mathbf{k N} / \mathbf{m}^{2}\right)\end{array}$ & $\begin{array}{c}\text { Suggested Support } \\
\text { Pressure in } \\
\text { Intersections } \\
\left(\mathbf{k N} / \mathbf{m}^{2}\right)\end{array}$ \\
\hline Ultramafic typical & 80 & 10 & 9 & 40 & 70 \\
Ultramafic weak & 25 & 5 & 7 & 50 & 90 \\
Ore typical & 10 & 1 & 2.5 & 130 & 220 \\
Ore weak & 1 & 0.7 & 2 & 170 & 290 \\
\hline
\end{tabular}

\subsection{Mining methods}

Bulk open stoping mining methods with post extraction backfill were used. The target was $100 \%$ extraction of the very high grade ore. The lode width generally exceeded that which could be recovered in a single slice. Therefore a two-pass slice strategy (and locally, three slices) was used to achieve a high extraction ratio. The first pass stopes were the footwall stopes, which were backfilled with cemented rock fill (CRF) 
prior to taking the next stope. Then the second pass hangingwall stopes were recovered from beside, and in some cases beneath, CRF-filled primary stopes (Figure 3). CRF strategy is described in Section 6. 
Table 4 Minimum ground support schemes for $6 \mathrm{~m}$ wide $\times 5 \mathrm{~m}$ high arched ore drives

\begin{tabular}{|c|c|c|c|}
\hline Scheme & Backs/Shoulders & Walls & $\begin{array}{l}\text { Standard Load } \\
\text { Capacity }\left(\mathrm{kN} / \mathrm{m}^{2}\right)\end{array}$ \\
\hline GSS 10 & $50 \mathrm{~mm}$ in-cycle fibrecrete & $50 \mathrm{~mm}$ in-cycle fibrecrete & Backs 280 \\
\hline Ore, no squeezing & $\begin{array}{l}3 \mathrm{~m} \text { resin bolts @ } 1.2 \times 1.2 \mathrm{~m} \\
\text { Mesh over fibrecrete } \\
\text { Spiling bolts }\end{array}$ & $\begin{array}{l}2.4 \mathrm{~m} \text { Split sets @ } 1.2 \times 1.2 \mathrm{~m} \\
\text { Mesh over fibrecrete to grade } \\
\text { line }\end{array}$ & Walls 230 \\
\hline $\begin{array}{l}\text { GSS } 14 \\
\text { Ore, under CRF or } \\
\text { with squeezing }\end{array}$ & $\begin{array}{l}\text { As above but with shotcrete } \\
\text { rib }\end{array}$ & $\begin{array}{l}\text { As above but with shotcrete } \\
\text { rib }\end{array}$ & $\begin{array}{l}\text { Backs } 780 \\
\text { Walls } 730\end{array}$ \\
\hline \multicolumn{4}{|l|}{ Component data: } \\
\hline \multicolumn{4}{|c|}{ Resin bolts: Minova T20 paddle bolt, $19.5 \mathrm{~mm}$ diameter. Plates $150 \times 150 \times 4 \mathrm{~mm}$. } \\
\hline \multicolumn{4}{|c|}{ Friction bolts: Split set Mining Systems Split set. Plates $150 \times 150 \times 4$ mm. } \\
\hline \multicolumn{4}{|c|}{ Fibrecrete fibre: Synmix $65,5 \mathrm{~kg} / \mathrm{m}^{3}$} \\
\hline \multicolumn{4}{|c|}{ Shotcrete ribs: Refer Section 5.} \\
\hline
\end{tabular}

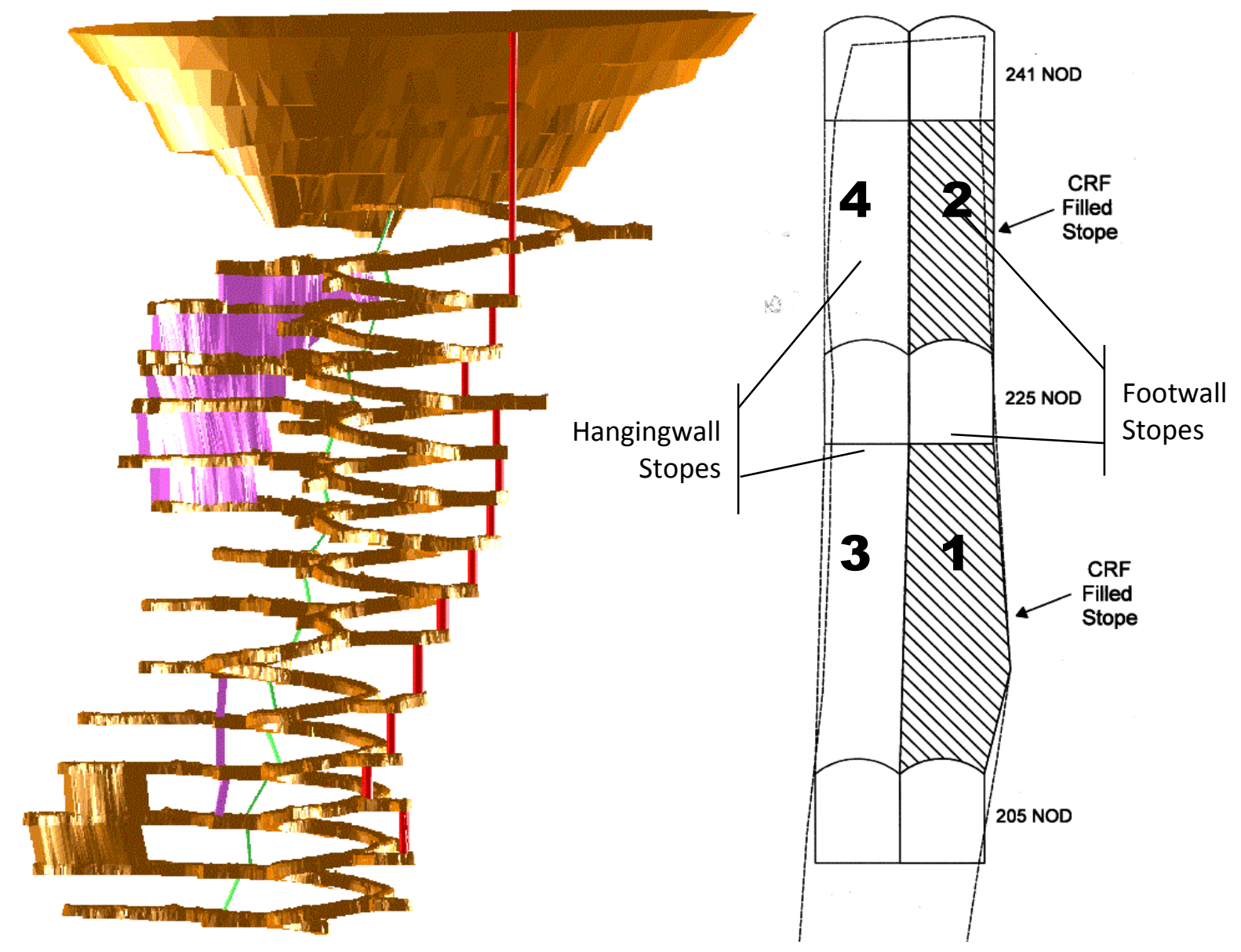

Figure 3 Mine layout showing (left) longitudinal view of an upper block extracted and a lower block in progress, (right) a typical cross-section of stope layout with bold numbers indicating extraction sequence 
Ore drives were parallel to strike and to foliation. Fortunately foliation was poorly developed in the ore and the immediate host rock else the degree of squeezing experienced would have been higher.

The design features of this method were:

- Stope access was by a footwall drive in the ore, then stoping and CRF backfilling of $6 \mathrm{~m}$ strike length primary stopes on retreat (Figure 3 ). On completion of the footwall slice, a hangingwall slice was taken in a similar manner.

- Large sill pillars separated a number of stoping blocks, for production rather than geotechnical reasons. Sill pillars were one level interval high. Sill pillars were only removed once the overlying and underlying stoping panels had been mined and backfilled.

- The sequence was to mine a footwall stope a long time (at least several weeks) ahead of its paired hangingwall stope. Geotechnically, the advantage was that the CRF in the footwall stope was then older and stronger.

- A standard stope strike length of $6 \mathrm{~m}$ was adopted, based on the stable/transitional demarcation in the Mathews Stability Chart analysis (Trueman et al., 2000). This suited both geotechnical and production requirements. It proved to be a good choice as very few cases of significant overbreak were encountered.

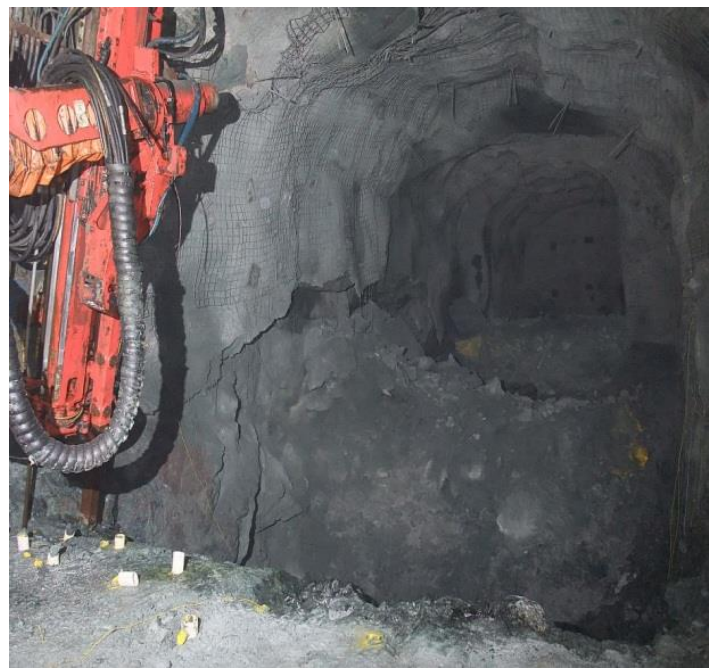

Figure 4 The Panel three stope void on 185 Level seen from above. Drillhole collars seen in the foreground are for the crush firing. The mound in the middle distance is the CRF of the previous stope after being punched up by the previous crush firing

All hangingwall stopes performed better than their footwall stope pairs, i.e. less squeezing, less closure, less brow instability. The favoured status of hangingwall stopes was because:

- they were dry - being drained by the footwall stopes,

- they were in destressed ground - the footwall void put the hangingwall areas into stress shadow, so squeezing pressures in backs were minimal, as most closure had already occurred during footwall development and stoping,

- they had stronger walls - a CRF east side wall and an ultramafic west side wall, whereas footwall stopes had a weak ore wall.

\subsection{Three firing types}

The mine used three classes of firings as follows: 
Production firings: These were conventional firings of the stope.

Crush firings: The mining method required immediate CRF filling of each stope to maintain stability and reduce wall convergence. Conventionally, this would require the drilling and blasting of a new slot rise for every stope. In order to avoid that, the practice was adopted to 'crush' or compact the CRF by blasting against it using pre-drilled blastholes immediately after CRF placement. A compression of about $20 \%$ in the CRF was achieved, creating sufficient space for the next production firing. Crush firings are described in Section 6.3.

Half-upper firings: These were designed to remove the intensive ground support in the ore access drives. Half-uppers were fired prior to both the crush firings and the production firings.

- The half-uppers for the crush firing removed the shotcrete rib and some of the adjacent ground support. Blastholes were also drilled in the shotcrete ribs themselves.

- The half-uppers for the production firing removed the remaining ground support for the stope. These half uppers created a good brow, and also protected the next shotcrete rib (the future stope brow) from the force of the main production rings.

\section{$4 \quad$ Squeezing ground}

Backs: Cracking and squeezing occurred in the backs of various ore drives (Figure 5). Essentially a skin of ore, usually $1 \mathrm{~m}$ and up to $2 \mathrm{~m}$ thick, squeezed and fractured, bulked in volume, and pushed down onto the fibrecrete skin, causing cracks. At the same time, horizontal stresses caused closure, sometimes causing shearing damage in the fibrecrete.

The damage usually first appeared some hours after blasting rather than immediately, and gradually worsened with time. Water in the drive above, if any, disappeared into the floor as the ground became fractured. In some instances drilling of boreholes had water return loss, and brow cables took excess grout - both indicating voids had opened in the backs.

Cracking and squeezing was more likely at depth, in a footwall drive, in wider spans, and under a sill pillar (i.e. high local percentage extraction). A sill pillar width/height ratio of 1:1 showed squeezing (the 185-200 sill) whereas a thicker pillar (ratio 1.67:1) did not.

Walls: Vertical squeezing occurred in walls and pillar noses, fracturing the weak ore lode rock and causing bulking (Figure 6). Fibrecrete initially cracked, then buckled into the drive, and winging (lifting of edges of fibrecrete away from the wall) was common. Damage developed gradually over time. Squeezing was worse where subvertical wall structure focussed stress between the excavation and the structure. 


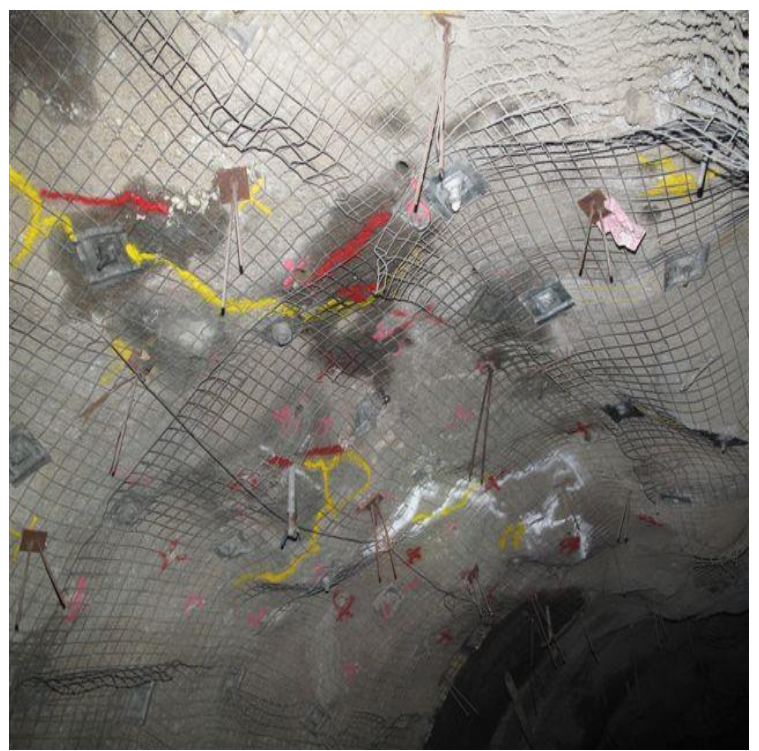

Figure 5 Cracking of fibrecrete in the backs of the Panel nine stope, 185 Level
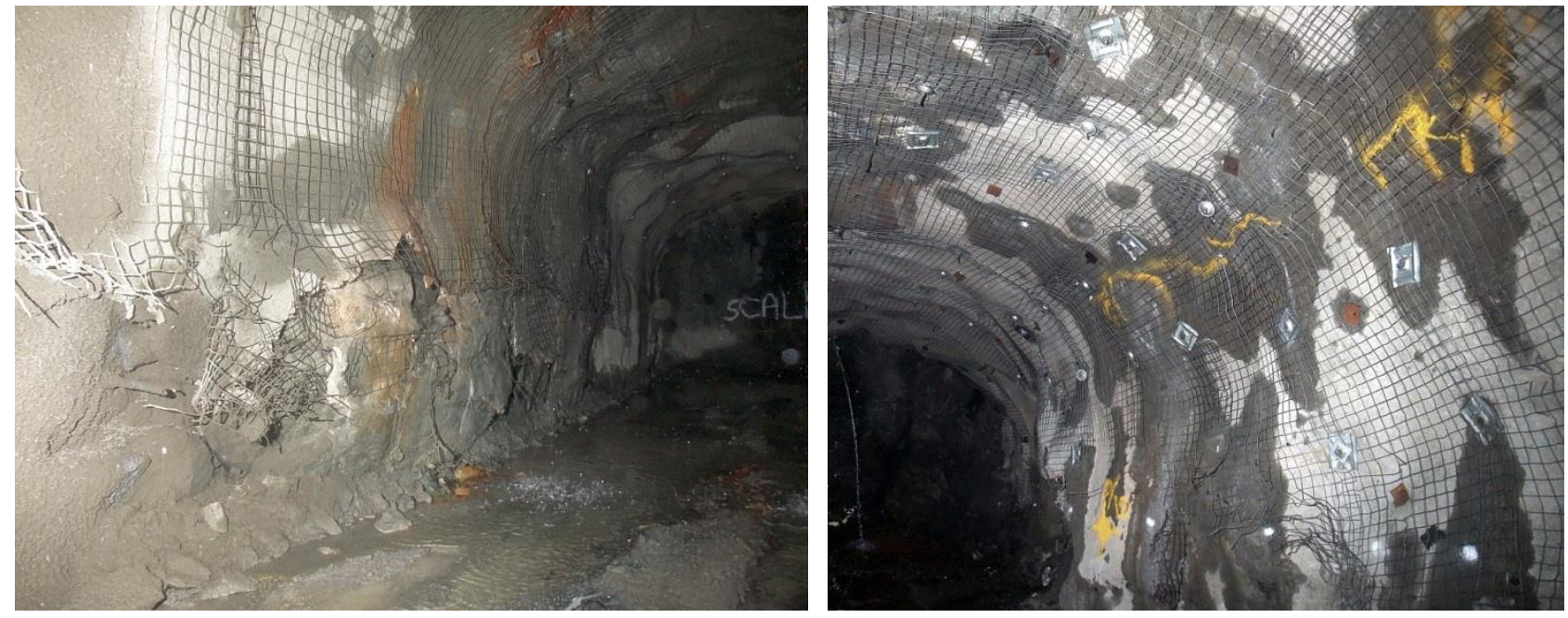

Figure 6 Squeezing in ore in walls at depth: (left) damage on 40 Level west wall, (right) damage exacerbated by water inflow (20 Level)

\subsection{The rate and amount of squeezing closure}

On the 125 footwall ore drive, survey prisms (Figure 7) and borehole camera observations were used to enable tracking of wall and back movements during development. The camera results indicated the rock mass was significantly fractured for a distance variably 0.2 to $0.8 \mathrm{~m}$ into the wall as soon as it was developed. Further localised damage was seen up to $1.5 \mathrm{~m}$ into the wall, and one camera hole was making water from a joint about $5 \mathrm{~m}$ into the wall.

In the 40 Level study, the survey prism data indicated horizontal closure of $33 \mathrm{~mm}$ (total both walls) and vertical of $13 \mathrm{~mm}$, from the installation of the prisms to the completion of the development stage. The horizontal closure by this time equated to $0.6 \%$ of the opening width in each wall. Unfortunately, damage to the prisms prevented this monitoring continuing into the production stage. On 125 Level, wall closures were about the same as on 40 Level during development, but backs closures were less. Maximum measured 125 Level wall closure was $113 \mathrm{~mm}$ (total) or nearly $2 \%$ of the opening width.

Movement rates varied in line with mining (being less during a passive period while mining was conducted elsewhere). The rate of passive period closure was the order of $0.4 \mathrm{~mm} /$ day in each wall. This compares to a peak active period rate measured at 1.0 to $1.2 \mathrm{~mm} /$ day in each wall. 
In many locations, it was possible to visually estimate vertical strain from the geometry of bulking of slabs in walls. Localised strains of up to $2.8 \%$ were estimated, which is quite high. Ground support schemes were tasked to contain the broken rock and prevent it unravelling. Over time, squeezing movements were sufficient to tear plates from bolts (but not from cable bolts which always remained intact).

Mercier-Langevin and Hadjigeorgiou (2011) presented a 'Hard Rock Squeezing Index' based on stress and foliation data from several mines. The Wattle Dam performance for the walls is indicated (Figure 8) and matches the Index expectations ( 1 to $5 \%$ strain). The ore performance is not shown because ore strength was too low and outside of the Index limits.

\subsection{Squeezing ground rationale}

If placed under sufficient stress, weak unconfined rock failed towards the opening soon after development. As the face moved on, stresses came to a new equilibrium, and movements slowed down.

Water exacerbated the failure and the movements. Groundwater is a destabilising influence in weak ground (effective stress principle). Groundwater was associated with a fall of ore in the 225 NOD, and with squeezing damage from 60 Level and deeper.

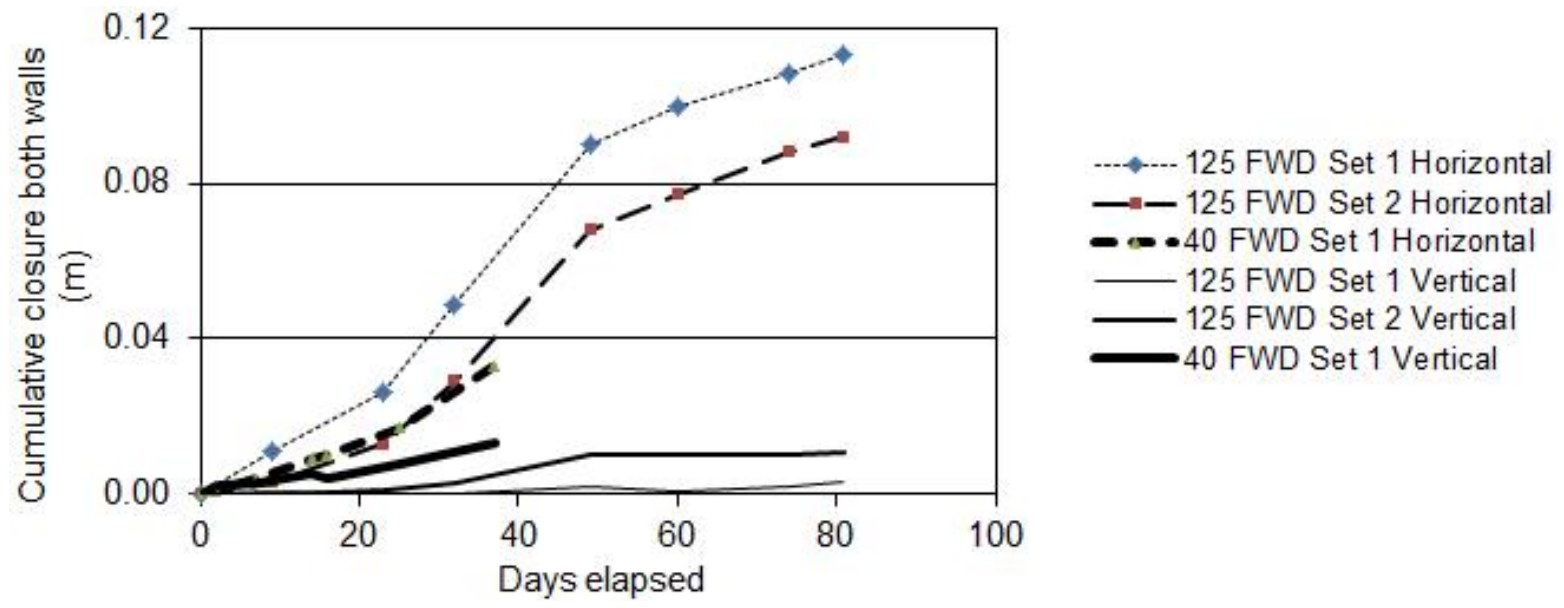

Figure 7 Survey prism data for closures in the 125 and 40 Level footwall ore development drives 

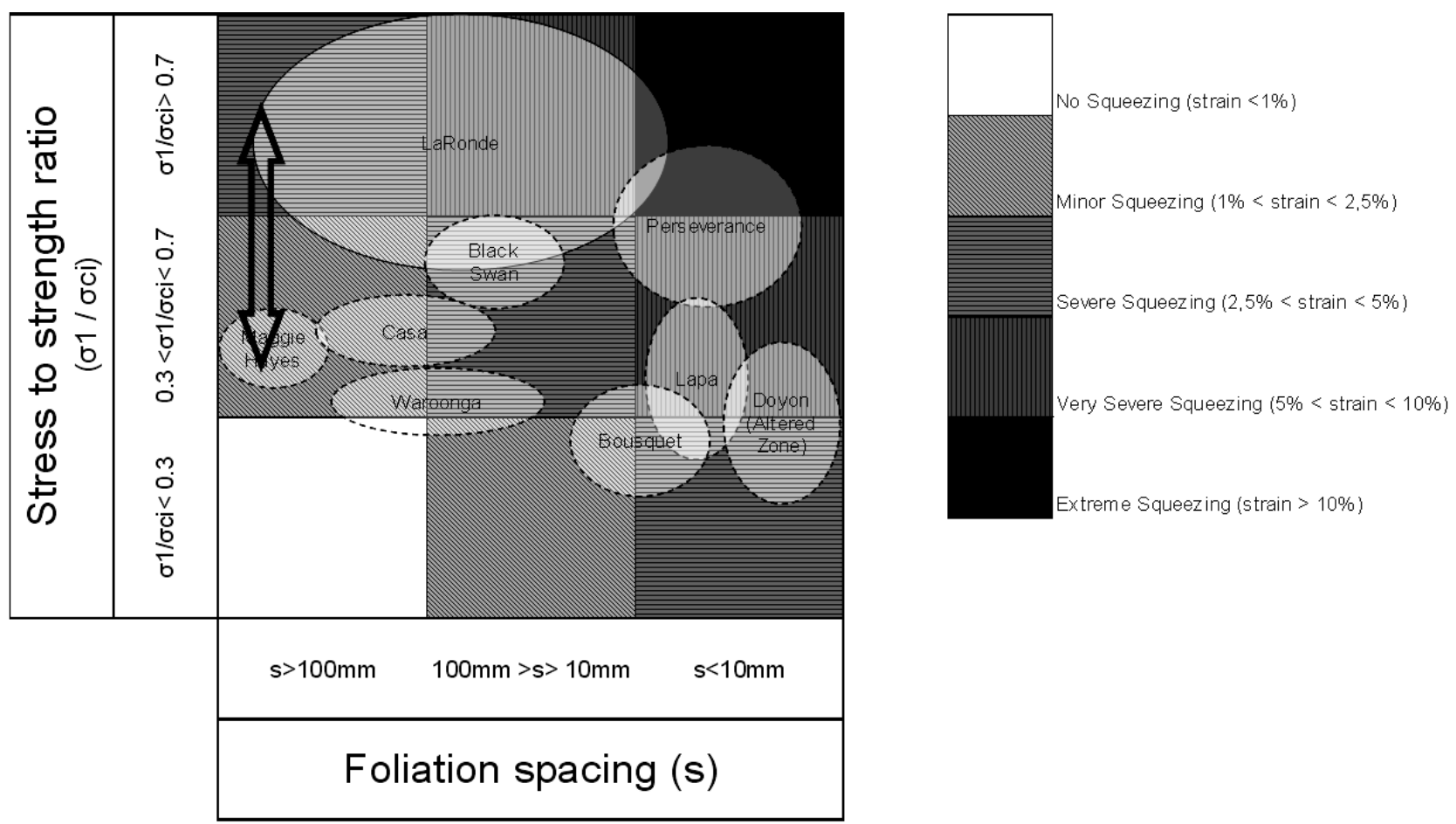

Figure 8 Wattle Dam hangingwall squeezing performance on the Hard Rock Squeezing Index (Mercier-Langevin and Hadjigeorgiou, 2011). The arrow indicates the range of performance at $300 \mathrm{~m}$ depth due to the range in strength

The strategy to control squeezing was:

- Apply initial in-cycle fibrecreting, followed by bolts and mesh, to lock up the walls, providing confining stress which opposed bulking and reduced the eventual final movement.

- After enough time and when the face had advanced away, install fibrecrete ribs, and rehabilitate as necessary with $100 \mathrm{~mm}$ fibrecrete and sometimes cables between the ribs.

Observations showed that most movement occurred as the face moved from 6 to $16 \mathrm{~m}$ away. Therefore ribs were delayed until the face was at least $10 \mathrm{~m}$ away and often more. The delay recognised that some squeezing and bulking was going to occur despite any practical level of ground support.

This approach has similarities with the New Austrian Tunnelling Method (NATM) described for example by Pascoe et al. (1995), Sauer (2003), and Karakus and Fowell (2004). First pass support is installed at development. Instrumentation is installed at development to track the movements and stress changes. As development continues, when the movements are judged to be stabilising, a strong second pass support is installed to lock up the rock mass and ensure long term stability.

Shotcrete ribs were not restricted to squeezing ground, but were also installed for other reasons, including wider spans, and under CRF backs. As there were no squeezing pressures in these situations, the ribs were installed close to the face.

\subsection{Shotcrete island pillars}

The mine also trialled the use of shotcrete island pillars (Figure 9) for support of squeezing ground in the 185 FWD backs under a particularly wide span $(9 \mathrm{~m})$. The pillars were successful, but were not as easy to fabricate as a rib, so were not used going forwards. 


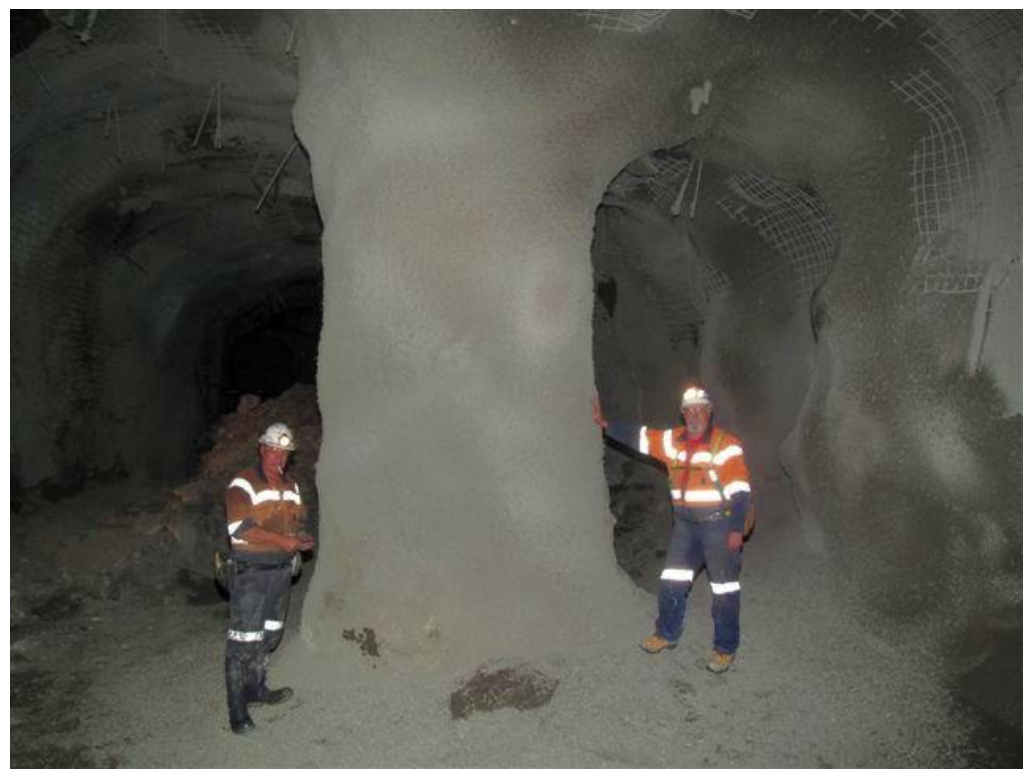

Figure 9 Shotcrete island pillars on the 185 Level

\section{$5 \quad$ The use and role of shotcrete ribs}

Ribs were used where a very high level of static support capacity was required. Ribs contained a mesh framework which was filled with sprayed fibrecrete. Ribs either comprised just the arch section (terminating in the upper wall) or included legs, depending on the strength of the wall and the purpose of the installation.

The estimated rib load capacity was based on the shear strength of fibrecrete. A rib of cross-section area $0.25 \mathrm{~m}^{2}$ had a nominal axial load capacity of $10,000 \mathrm{kN}$, and a shear strength capacity of $300 \mathrm{kN}$. Due to the geometry of the rib (it had depth) it was resistant to buckling, and was able to achieve transfer of loads from the backs into the legs of the rib and then into the walls. Overall support capacity provided by the typical pattern of ribs, i.e. spacing of $6 \mathrm{~m}$ along a drive of span $6 \mathrm{~m}$, was estimated as at least $500 \mathrm{kN} / \mathrm{m}^{2}$.

Some industry examples of the use of shotcrete ribs and arches are given by Chan and Shen (2008) and Li (2005).

\subsection{The construction of ribs - mesh bending machine}

The site enjoyed the use of a mesh bending machine, designed and built in-house by a contractor employee, for the preparation of mesh for the shotcrete ribs (Figure 10). Various profiles could be formed by this machine. The one most used for shotcrete rib mesh was formed from a mesh sheet $4.5 \mathrm{~m}$ long by $1.0 \mathrm{~m}$ wide. A piece of $300 \mathrm{~mm}$ width was bent up along each long edge of the mesh sheet.

The arch or rib was shaped and constructed to withstand compression and reduce the risk of the snapthrough failure mechanism operating. The mesh cage was first bolted to the rock, then the cage was filled with shotcrete (Figure 11). For best rib performance, significant steel content was positioned at the free outer edge of the rib, furthest from the rock. 


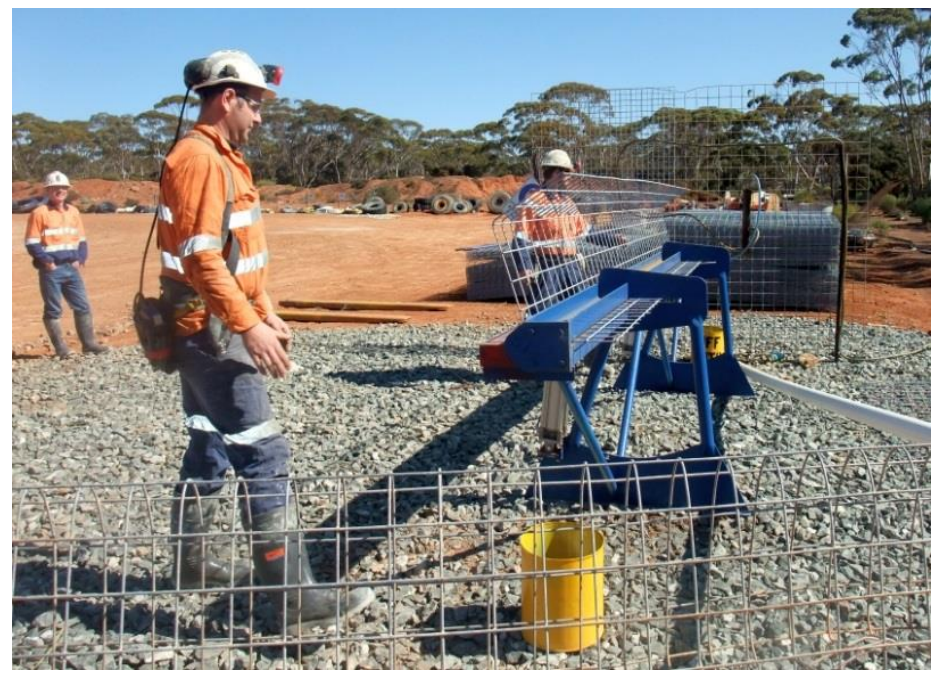

Figure 10 Mesh bending machine

\subsection{The performance of ribs}

Generally during stoping, the ribs were stable. Ribs performed as least as well as fibrecrete skins in containing poor ground. Fibrecrete skins tended to crack and bulk, despite more shotcrete going into the skins compared to the ribs. As well as in squeezing ground and for support under CRF, ribs were used for rehabilitation, and for brows (Figure 11). Shotcrete ribs at ore drive brows were useful, because in effect they lowered the height of the backs, bringing the rill point lower, and increased safety for bogging.
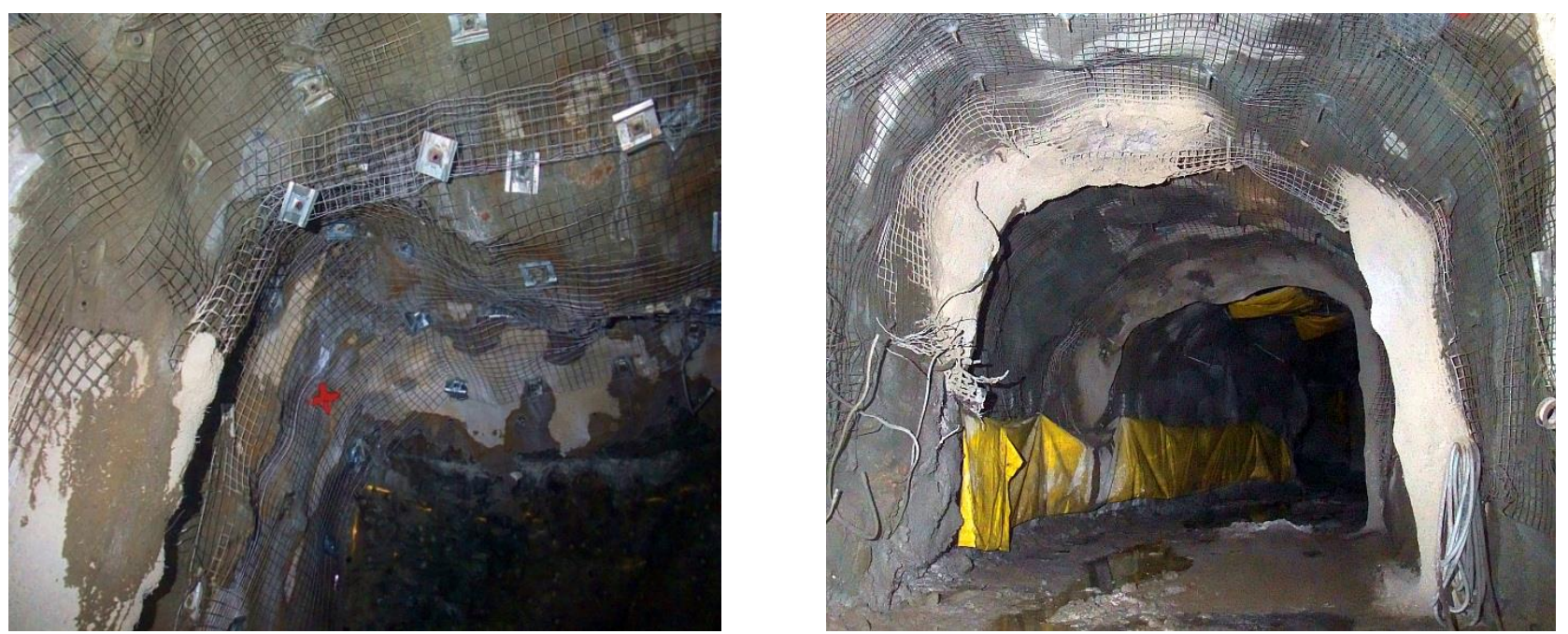

Figure 11 Examples of mesh cage attached to rock, with portions being filled with fibrecrete 

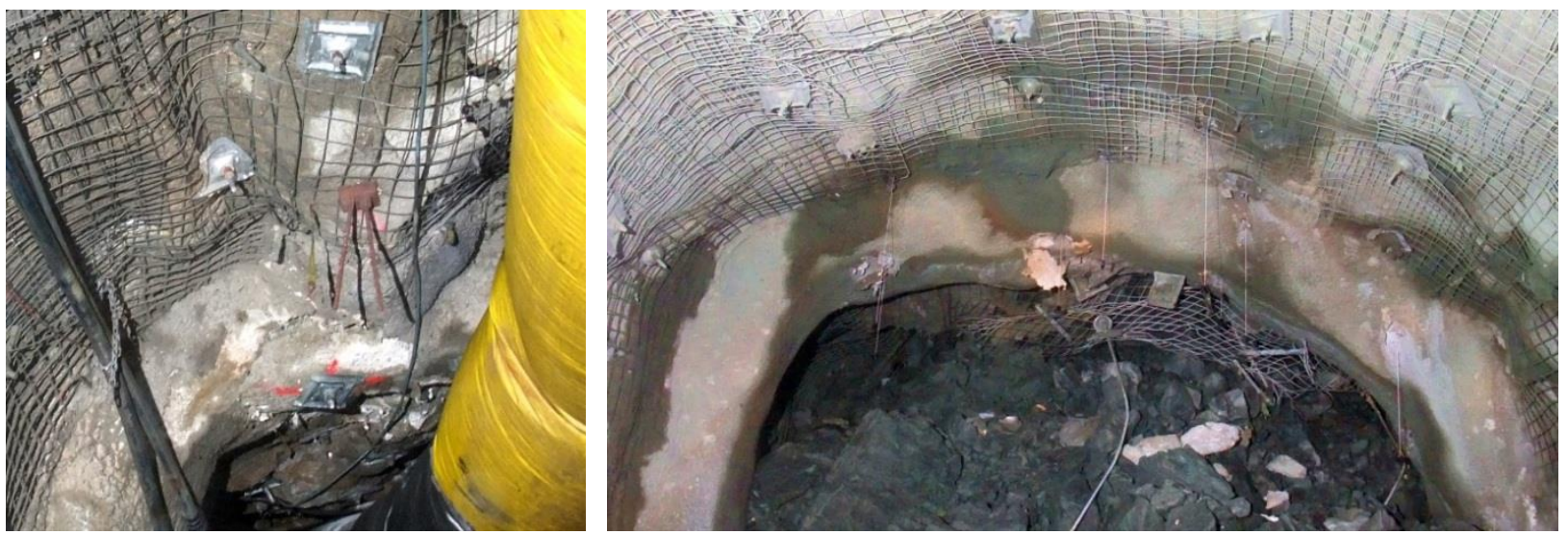

Figure 12 Shotcrete ribs (left) for control in squeezing ground, with significant deformation prior to the rib being installed, and (right) installed for support of a stope brow

Ribs were preferred over cables as they provided much more support. However they were stiff and strong, and could not withstand very much deformation. Therefore rib timing was important in squeezing ground, as previously described.

Several types of damage were observed to occur to ribs:

- Spalling, or cracking parallel to the surface of the rib (Figure 13). Thin plates of fibrecrete outside the mesh cage separated off. Spalling damage was managed by periodic check-scaling of the ribs.

- Cracking across the thickness of the rib to form a hinge (Figure 13). This occurred due to lateral loading (perpendicular to the rib axis).

- Shearing damage (Figure 14) due to high axial compressive loading in the rib due to closure of the ground. Rarely, a rib had to be re-secured with bolting. Ribs nearly always survived for the life of stoping on a level. In general the ribs brought equilibrium to the bulking in the backs.

- Blast damage (blastholes too close to the ribs) causing enough lateral loading to buckle the ribs.
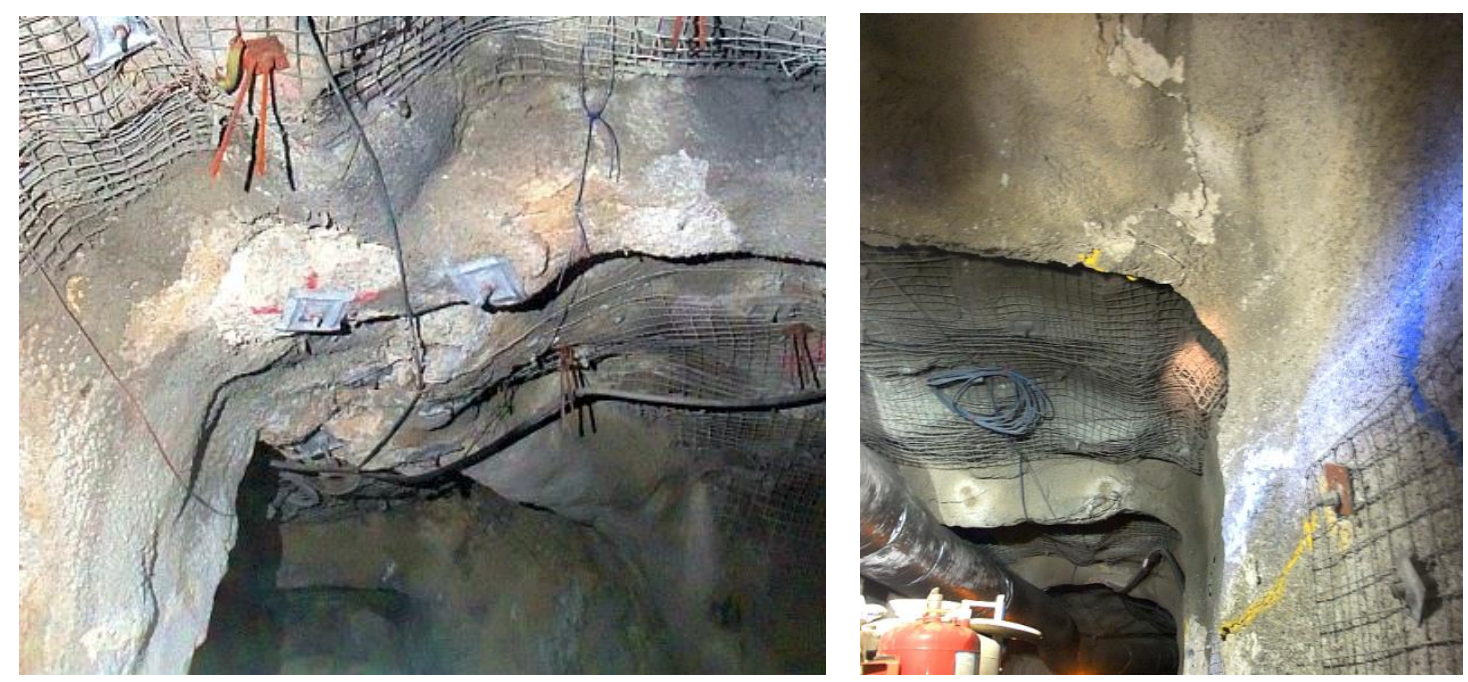

Figure 13 (left) surface spalling, and (right) hinge failure developing in a rib

\section{The use and role of CRF and crush firings}

CRF suited Wattle Dam with its small stopes and placements where quality control was more easily managed, and segregation could be avoided (Figure 15). 


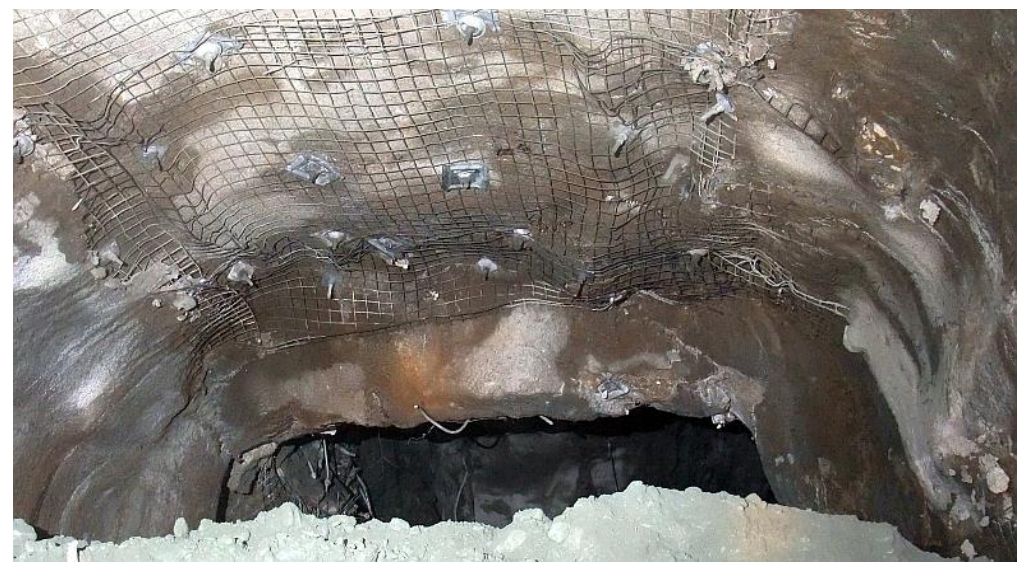

Figure 14 Shearing failure in a rib

\subsection{CRF mix and placement}

CRF preparation commenced with the mixing of a specified quantity of grout slurry at a surface plant. The batch of grout was then reticulated underground via a borehole system to the required level location. The grout poured out into a mixing cuddy and directly onto five or seven buckets of waste rock which had been prepared in the cuddy. The mix was trammed into the stope, and the process repeated until the stope was full. A stope could be filled in 13 hours in the absence of interruptions.

Laboratory tests of large samples for the design of backfill gave $2.2 \mathrm{MPa}$ and $2.5 \mathrm{MPa}$ strength at $5 \%$ cement. The adopted design strength was $3.5 \mathrm{MPa}$ at 28 days. Walls of CRF at this strength stand extremely well. CRF usage parameters were:

- Cement content in footwall stopes was normally $5 \%$, thus $1 \mathrm{~m}^{3}$ cement required for $25 \mathrm{~m}^{3}$ fill, or $3 \mathrm{t}$ slurry to $60 \mathrm{t}$ of waste rock (called a five-bucket mix). However, cement content was reduced to $3.5 \%$ (a seven-bucket mix) in hangingwall stopes which were final stopes where CRF was not exposed by any future mining.

- Cement slurry design was $1,180 \mathrm{~kg} / \mathrm{m}^{3}$ cement. GP cement was used.

- Minimum seven days curing time before being exposed by adjacent mining (except for the crush firing).

- The waste rock for CRF comprised both sediment and ultramafic. Some of the ultramafic was low strength, which was a factor in the success of the crush firings which are described later.
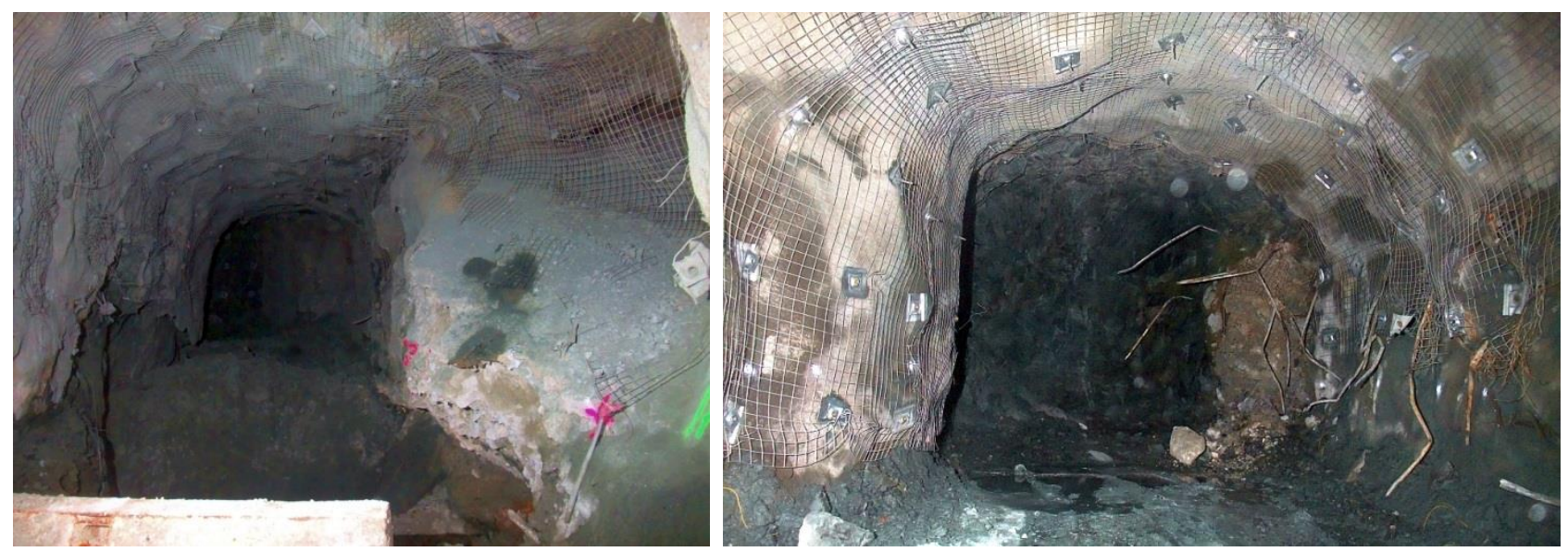

Figure ${ }_{15}$ CRF examples: (left) CRF forming a stope wall, (right) development of a HW drive (centre) alongside a CRF-filled FW drive (right) 


\subsection{CRF function}

CRF performed as expected, except once when a fall occurred due to a cold joint above the backs. Cold joints were formed at time-interruptions to CRF batching placement, and adversely affected stability if undermined. Also, CRF forming the floor of a drive was covered with dust/mud and became a future cold joint. A vertical but irregular cold joint in the CRF existed between the FW and HW panels. Vertical joints were less of a problem (being clamped by stresses, irregular profile) but were release surfaces for other potential failures.

Strategies for mining under CRF were:

- Designs considered where adverse cold joints may locate, and modified ground support to make the cold joints tolerable. The standard practice for mining under CRF became to place shotcrete ribs at $6 \mathrm{~m}$ spacings along the drives, i.e. one rib per stope. The rib supported the section of CRF that was at risk of a cold joint. A spin-off benefit was that the rib formed a good brow for the bogging of each stope.

- In some cases, additional ribs were placed where the CRF was judged to be more adverse irregularities in cement content, or not fully tight filled.

- The CRF base varied with traffic furrows, potholes, and fugitive roadfill. Where development under CRF was required, early practice was to blast about $0.4 \mathrm{~m}$ below the expected CRF and allow/promote falloff to the CRF. Washing down before fibrecreting ensured loose material was removed. Later practice was to mine out the lowest $1 \mathrm{~m}$ of $\mathrm{CRF}$, to ensure the new drive backs were positioned above any potential poor quality patches. No mesh or other reinforcing was placed in the CRF.

\subsection{CRF crush firings}

In order to avoid the need to blast a conventional slot rise for every stope, the practice was adopted to crush the CRF by blasting against it soon after placement.

Crush firings had a comparatively higher powder factor, and this energy could damage the adjacent brow. Sometimes this meant propagation of overbreak into the brow. In comparison, production firings had less energy and tended not to cause brow damage. The positions of ends of blastholes were checked (weights on strings were observed) and excessively deviated holes were redrilled.

Firing of the CRF crush rings was a little less effective for longer blasthole lengths, compared to shorter geometry stopes. It was thought that ore displaced in the crush firing did not clear the slot as quickly for the longer hole lengths, and some of it became compressed into the CRF or into stope corners rather than falling to the bottom.

CRF was deformable by slot blasting up to 20 hours after placement. After that time it gained too much strength to allow successful crush firing. Therefore designs either facilitated rapid CRF placement, or did not depend on CRF deformation by blasting. A crush firing blasthole array is shown in Figure 16.

The shorter the time between placement and crush firing, the greater the compression or 'punch-back' of the CRF that was achieved. Compressions of about $20 \%$ were regularly obtained by the blast. This increased the CRF bulk density, but at the cost of breaking some of the cement bonds. The strength of the CRF was due in part to the tightness of packing of the CRF particles after the blast.

For a five-bucket CRF mix, the crush firing achieved a punch-back of about $1.5 \mathrm{~m}$. This means that the CRF was compressed by $1.5 \mathrm{~m}$, placing the CRF endwall of the new stope $1.5 \mathrm{~m}$ further back. The new stope void, once completed, was $7.5 \mathrm{~m}$ in strike length rather than the nominal $6 \mathrm{~m}$. For the weaker seven-bucket $\mathrm{mix}$, the punch-back was 2 to $3 \mathrm{~m}$ (based on visual observations). 


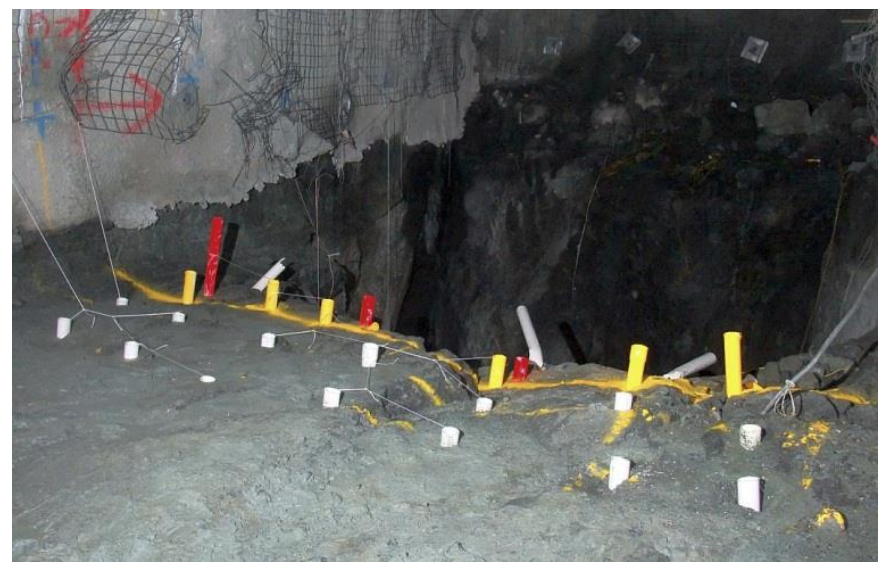

\section{Figure 16 Crush firing blasthole pattern indicated by collars. Weights on cords are suspended in the holes for visual check of hole toes on the level below}

\section{Conclusions}

The Wattle Dam ground support strategy was successful because of due attention given to observing performance, combined with willingness to introduce, modify and develop best practice in some less common ground management techniques. By the end of mine life, the shotcrete arches routinely installed by the Contractor were works of art as much as effective ground support.

A key outcome was that adequate support in squeezing ground depended on timing as well as capacity the flexible initial support, followed after due time by a stronger second pass for long term stability. The shotcrete ribs provided this support and almost always survived to the completion of stoping.

The crush firings and CRF performance were likewise effective elements in the success of the mining strategy. The ability to undermine the CRF and support it with shotcrete ribs was an integral part of the strategy to achieve full extraction of the orebody.

\section{Acknowledgement}

The authors admire the skill of HWE Mining (now Leighton) in shotcrete arch construction to suit the mine. The authors gratefully acknowledge the Wattle Dam management, engineers and operators for their support, and Ramelius Resources for permission to publish this paper.

\section{References}

Barton, N.R., Lien, R. and Lunde, J. (1974) Engineering classification of rock masses for the design of tunnel support, Rock Mechanics and Rock Engineering, Springer, Vol. 6 (4), pp. 189-236.

Chan, I. and Shen, B. (2008) Use of shotcrete arch as tunnel support - a case study, in Proceedings 13th Australian Tunnelling Conference, Melbourne, May, pp. 71-76.

Karakus, M. and Fowell, R.J. (2004) An insight into the New Austrian Tunelling Method (NATM), in Proceedings ROCKMEC 2004 VIIth Regional Rock Mechanics Symposium, Sivas, Turkey, $14 \mathrm{p}$.

$\mathrm{Li}, \mathrm{C}$. (2005) Ground control of a mine stope in weak rocks subjected to high in-situ stresses - a case study, in Proceedings 24 th International Conference on Ground Control in Mining, Morgantown, pp. 203-207.

Mercier-Langevin, F. and Hadjigeorgiou, J. (2011) Towards a better understanding of squeezing potential in hard rock mines, Mining Technology, Vol. 120, No. 1, pp. 36-44.

Pascoe, M.J., McGuckin, P.H. and Logan, A.S. (1995) Operational rock mechanics at the Cannington exploration decline, in Proceedings AusIMM Underground Operators' Conference. Kalgoorlie, November, pp. 57-62.

Sauer, G. (2003) Ground support and its toolbox, in Proceedings Earth Retention Systems 2003: A Joint Conference of the ASCE Metropolitan Section Geotechnical Group, the Deep Foundations Institute, and ADSC The International Association of Foundation Drilling. New York, May, pp. 204-224.

Trueman, R., Mikula, P., Mawdesley, C. and Harries, N. (2000) Experience in Australia with the application of the Mathews method for open stope design, CIM Bulletin, Vol. 1036, pp. 162-167. 
